\title{
Problemas e perspectivas sobre o ensino de Evolução
}

\author{
Francisco José de Figueiredo \\ Doutor em Ciências Biológicas (UFRJ), \\ Professor Associado do Departamento de Zoologia (UERJ) \\ $\triangle$ fjfig2020@outlook.com
}

Evolução é um conceito-chave para o ensino das Ciências Biológicas pois integra áreas diversas do conhecimento científico em torno da ideia de relações parentesco entre todos os seres vivos devido a herança compartilhada de mudanças no material genético. Esse padrão de descendência com modificação é representado sob a forma de um diagrama ramificado a árvore filogenética -, na qual todas as espécies compartilham ancestrais em comum em níveis de generalidade diferentes. E, como se sabe, coube a Charles Darwin, em 1859, propor o principal mecanismo evolutivo - a seleção natural -, responsável pelas adaptações, os finos e graduais ajustes entre os fenótipos dos organismos e o ambiente.

Uma vez que os processos evolutivos subjacentes à árvore decorrem de causas naturais, a criação de novas espécies a partir de espécie ancestral comum também o é. Com isso, a espécie Homo sapiens foi retirada de uma condição à parte da natureza - como o ápice de uma criação especial divina - e passou a ser tratada como outra qualquer dos ramos da árvore da vida, sujeita aos mesmos dramas evolutivos e condenada a se extinguir em dado momento.

A revolução darwinista causou um "abalo sísmico" na história da cultura ocidental; foi um golpe fatal contra o antropocentrismo e um triunfo do materialismo. Completou um processo iniciado pelo cônego Nicolau Copérnico (1473-1543), no séc. XVI, que culminou com a refutação do geocentrismo e a aceitação do heliocentrismo. A Terra deixou de ser o "centro do universo" para ser um planeta a mais cumprindo órbita em torno do sol.

Com Darwin, a biologia tornou-se ciência moderna, desvinculando-se do ranço da teologia judaico-cristã e adquirindo viés naturalista ${ }^{1}$. Sua proposta demonstrou ser a melhor

\footnotetext{
${ }^{1}$ Naturalismo, enquanto postura metodológica, implica no descarte do sobrenatural como explicação racional da realidade objetiva. Não nega a sua existência, mas, pelo fato de se apelar para entidades metafísicas, o argumento se torna intestável. Essa postura tem dado certo na história moderna das ciências, funcionando como algo do tipo: "time que está ganhando não se mexe". Portanto, é diferente do naturalismo metafísico ou materialismo dialético.
} 
explicação para os sistemas viventes. Passou a ser uma referência para decisões tomadas quanto à proteção de espécies ameaçadas de extinção, combate a doenças endêmicas e engenharia genética.

Evidentemente, a perspectiva darwinista tem implicações um tanto incômodas numa sociedade moldada pela tradição judaico-cristã. Entra em choque com correntes ideológicas conservadoras e isso interfere na qualidade do ensino, uma vez que muitas instituições de ensino estão vinculadas a organizações religiosas.

E, nesse contexto, para o professor, a sensação, muitas vezes, é a de estar amordaçado ou "pisando em ovos", uma vez que certas "verdades" (=implicações) se apresentam como proibidas de revelação explícita, devendo ser contornadas ou disfarçadas, com o objetivo de se enquadrar numa ética manipulada para não contrariar o status quo. A situação nos remete ao caso ocorrido numa reunião da Associação Britânica para o Progresso da Ciência, em 1860, onde ocorreu o famoso debate entre o "buldogue" de Darwin - Thomas Henry Huxley - e o conservador bispo Wilberforce, sobre a descendência do homem. Na ocasião a esposa do bispo teria comentado: “descendentes de macacos, por Deus! Esperamos que não seja verdade; mas se assim for, rezemos para que não chegue a ser de domínio público".

Mesmo com tantas fontes de informação disponíveis, que vão desde os convencionais livros e artigos até sites na internet, o tema evolução tem sido negligenciado, distorcido, descredenciado, omitido ou, até mesmo demonizado, em sala de aula. O resultado é um domínio bastante deficiente e superficial do assunto por parte de professores e alunos. Basta um bate-papo de poucos minutos com amigos leigos ou eruditos para constatarmos discrepantes entendimentos, dependentes do ambiente sociocultural no qual a pessoa está inserida.

Entre as principais causas da deficiente compreensão da evolução, está na falta de treinamento dos professores do ensino médio sobre Filosofia da Ciência e compreensão precária das evidências que suportam a teoria. Sendo assim, os alunos têm ingressado nas universidades com compreensão deficiente de conceitos científicos, não distinguindo ciência de outras formas do saber e, com isso, querendo externar suas impressões particulares sobre evolução. 
Muitos se conformam com o conhecimento que lhes foi passado e imposto desde a infância. Manifestam verdadeiro pavor pela busca da verdade porque isso pode abalar suas convicções pessoais. Outros até possuem pensamento crítico, mas a educação básica deficiente constitui barreira eficiente para a compreensão de conceitos e evidências, pior ainda na assimilação. Há aqueles com boa educação e cultura que lhes permitem compreender, assimilar e até visualizar aplicações da teoria de evolução. Porém, nesses a maior dificuldade está em reconhecer as implicações; algo do tipo: "se isso ocorre, então (...)". Em outras palavras, se uma hipótese é baseada em robustas evidências empíricas, tem elevada capacidade de explicação e geração de consequências testáveis, aqueles argumentos contrários, sem evidências e camuflados com explicações ad hoc, devem ser falsos.

Em linhas gerais, as principais causas da falta de assimilação de conceitos da biologia evolutiva são:

i) conhecimento inadequado do conteúdo da Teoria de Evolução por Seleção Natural associado à falta de compreensão das evidências empíricas que a sustentam;

ii) treinamento deficiente em Filosofia da Ciência;

iii) influência do fundamentalismo religioso;

iv) miscelânea de fatores psicológicos, políticos e sociais.

Desses, a falta de compreensão das evidências empíricas da evolução e o precário (ou nulo) conhecimento de filosofia da ciência por parte dos professores são os que contribuem mais significativamente para o fenômeno.

A estranheza ou relutância quanto à assimilação de conceitos científicos, tem levado ao apartheid ${ }^{2}$ cognitivo. Ao se esquivar do confronto com novas ideias, evita-se o conflito existencial e a exclusão social. Assim, o indivíduo pode se manter estável numa zona de conforto. De raiz psicológica, essa postura ilustra a tendência humana pela busca de evidências que confirmem suas ideias ou convicções pessoais e nunca àquelas que possam

\footnotetext{
${ }^{2}$ Diz-se do desenvolvimento de um sistema ideológico autoimune, com o objetivo de evitar que aquilo que se crê seja demonstrado falso por validação externa.
} 
confrontá-las. Há um medo profundo de que seja demonstrado que tudo aquilo que vinha sendo dito como verdade desde a infância não passe de uma imensa tolice.

E, como são seres humanos, muitas vezes os cientistas também não escapam desses vícios, tornando-se resilientes, ao defenderem a todo custo suas hipóteses e teorias, apelando para explicações ad hoc. Podem distorcer fatos, ajustar dados na moldura teórica em que se sentem mais confortáveis, criar análises equivocadas e até emitir interpretações inconsistentes. Essa imunidade ideológica pode ser bastante forte na comunidade científica, atrasando de forma considerável novas tendências.

A rejeição ou mal entendimento do significado moderno da evolução pelo público leigo, como não poderia deixar de ser, também está condicionada à perpetuação e difusão de mitos. Muitos deles têm suas origens nos primórdios da humanidade (e.g., pecado original, dilúvio universal, torre de Babel, Scala naturae) e outros, mais modernos (e.g., darwinismo social, eugenia, elo perdido) encaminharam novos rumos.

Os mitos inspiraram a introdução de valores éticos e morais e são ainda usados para legitimar aspectos da vida cultural, tais como costumes, crenças, instituições e rituais, desempenhando papel ativo na modelagem social.

O processo de criação dos mitos é psicológico, um aspecto essencial da psique humana. Eles são mantidos pela crença e fortemente assumidos como verdades, mesmo com todas as evidências adversas. São muito resilientes: quando pensamos que foram definitivamente descartados, voltam com força total, dependendo das circunstâncias. Alguns, de tão antigos, passaram a fazer parte do inconsciente coletivo.

$\mathrm{Na}$ fixação do mito, uma vez apreendida a sua "verdade" oculta, segue uma fase de obtenção de satisfação e autoconfiança pessoais, com a eliminação de possíveis dúvidas e incertezas instigadas por ideias contrárias. No caso de mitos religiosos, a fase final representa a apreensão de uma "verdade suprema", praticamente uma comunicação transcendental. É a aceitação, sem contestação, do dogma e da sua mensagem intrínseca. Como consequência, a zona de conforto gerada é protegida a todo custo, pela demonização, depreciação ou imunização de contraexemplos. Os arquétipos atrelados a certos mitos estão tão consolidados no inconsciente popular, que o questionamento deles pode levar a uma perda de identidade individual ou, até mesmo, a uma catástrofe moral. 
A eficácia do mito requer repetição literal, como um mantra, até se tornar um dogma. Parte do pressuposto de crer primeiro para ver depois. Infelizmente, isso é o que se verifica nas crescentes ondas de fideísmos, fundamentalismos, negacionismos, superstições, pseudociências e "teorias" de conspiração que assolam esses tempos modernos, aproveitando-se de crises econômicas e sociais de todos os tipos.

De uma forma geral, o impasse entre evolução e religião na sociedade moderna reside na aceitação de uma criação natural - baseada em evidências empíricas positivas -, em oposição a uma criação sobrenatural, sustentada por mitos, fábulas e lendas. E na história do pensamento ocidental, a criação sobrenatural muitas vezes, mas não necessariamente, esteve associada ao mito da fixidez, permanência ou imutabilidade das espécies e uma criação em ato e não em potência. O uso de linguagem literal ${ }^{3}$, ao invés de simbólica, por parte de fundamentalistas religiosos também tem contribuído para o impasse.

Em tempos de pandemia, em que se fala de novas variantes da COVID-19, com vantagens para o vírus ao garantir-lhes maior disseminação e infectividade, é surpreendente que conceitos científicos básicos, como mutação, variabilidade genética, adaptação e seleção natural, ainda sejam nebulosos a ponto de dar espaço para o reaparecimento de antigos mitos e a propagação de "teorias" conspiratórias.

Mesmo com a imensa quantidade de informações científicas na internet, muitas delas consolidando descobertas científicas em substituição a antigos mitos, é recorrente a desconfiança popular e a procura de apoio nos mitos. Temas como a posição do homem na natureza evidenciada pelo estreito relacionamento genético com os demais primatas e ainda, o parentesco estendido aos demais seres vivos, até chegar no ancestral comum mais remoto - aquele com aspecto próximo de uma bactéria -, ainda constitui verdadeiro tabu. Para muitos, é algo inconcebível.

Em países com forte disfunção social, em que o assistencialismo estatal é nulo ou deficiente e correntes fundamentalistas assumiram as rédeas do poder, o terreno é ainda mais propício para a difusão de fakes de todos os tipos quanto a história da vida na Terra. 0

\footnotetext{
${ }^{3}$ A adoção de uma linguagem literal na interpretação das "sagradas escrituras" como sendo "a palavra de Deus" não faz qualquer sentido, pois faltam os documentos originais para aferição. O que se tem é uma imensa colcha de retalhos moldada por copistas e revisores segundo interesses particulares em épocas diferentes.
} 
pensamento crítico é deixado de lado e a conviç̧ão da credibilidade científica de textos religiosos é exacerbada. Nesses casos, é comum a forçada integração de intervenção divina com o processo evolutivo, como explicações indistintas, num contexto de concordância não excludente. Essa postura indica o não reconhecimento da evolução como ciência e, particularmente, como ciência histórica. É reflexo do desconhecimento do que vem a ser um processo de investigação científica. 0 resultado é ignorância difusa.

Por tudo isso, há muitas ideias equivocadas sobre evolução enraizadas no público leigo (mas também, entre muitos professores!). E muitas delas são mitos trazidos pelos alunos que chegam às universidades. Entre os mitos, destacam-se:

1) Marcha do progresso. - A ideia de que a evolução ocorre em linha reta, como um processo contínuo de aperfeiçoamento e depuração, dos estágios mais simples aos mais sublimes de complexidade e adaptação. Trata-se de um dos maiores equívocos sobre a evolução, muito exaltada pela mídia. Corresponde a uma visão teleológica ou finalista na qual uma trajetória predeterminada é cumprida, com sucessivas etapas imperfeitas, até se atingir uma condição final de perfeição. Consequentemente, visualiza o homem como o objetivo final de uma escalada de progresso na natureza. Essa percepção tem suas raízes no velho mito da Scala naturae e suas derivações (e.g., transformismo e evolução espiritual). Mas, sendo evolução um processo histórico, ela é constituída de eventos únicos, irrepetíveis, de quebras e progressões de linhagens ligados eventuais contingências. O padrão gerado para todos os seres vivos - a árvore filogenética - é ramificado e arborescente, nunca em linha reta. A história particular de cada espécie nos mostra engenhosas soluções para problemas impostos pelo ambiente em constante mudança. As soluções - as adaptações - são circunstanciais, numa situação singular espaço-temporal. Com base nas novidades evolutivas adquiridas e nas inovações que elas proporcionam, oportunismo e seleção natural trabalham na exploração e ajuste, respectivamente, às condições impostas. Em outras palavras, como em um processo de bricolagem, é o que deu para ser com o que se tem. A perfeição é somente aparente. Mudando a regra do jogo, aquilo que era "quase perfeito", deixa de ser. E a variabilidade genética ("cartas na manga") deve ser suficiente para encarar as novas situações adversas. 
2) Evolução retrógrada. - Muita gente acredita na evolução, mas a percebe como um estranho processo retrógrado, de degradação ou degeneração progressiva, após uma suposta "idade de ouro" da humanidade. É uma perspectiva contrária à da marcha do progresso e igualmente equivocada, uma visão saudosista sob forte ideologia religiosa. No caso das religiões monoteístas de raiz judaica, apela-se para a "queda" ou "vacilo" da humanidade - o mito do pecado original e a expulsão do casal original do paraíso. Por outro lado, os mesmos arquétipos podem ser identificados em antigos mitos que falam de conflitos entre deuses e forças telúricas, como no caso da revolta dos titãs da gigantomaquia mitologia greco-romana e seus sobreviventes. Seja como for, não há qualquer evidência empírica ou racional para essa visão distorcida de "evolução". No entanto, essa ideia de processo retrógrado nos chama a atenção para o fato de que evolução nem sempre implica em aumento de complexidade; há vários casos em que a simplicidade foi a opção mais vantajosa, às custas de perdas de estruturas e funções, até a aquisição de incríveis especializações (e.g., formas parasitas em comparação com parentes de vida livre).

3) Transformação por mutações acumuladas. - Trata-se de um mito moderno que diz que as espécies se transformam por mutações acumuladas no material genético em associação com fatores ambientais. A intensidade ou magnitude das mutações levaria ao aparecimento de novas formas discrepantes ("monstros esperançosos"). É uma reedição do mutacionismo, do geneticista Hugo De Vries (1848-1935), comum entre os geneticistas da primeira metade do século XX. A explicação se aproxima daquela usada para a origem dos famosos super-heróis da série americana X-Men, que adquiriram grandes mutações no material genético e com isso, superpoderes a ponto de não mais reconhecerem os antecessores normais como sendo do seu próprio tipo. Assim, esses mutantes passaram a viver isolados, formando uma comunidade reprodutiva particular. Esse mito indica que as mutações, somente elas, são responsáveis diretas pela evolução, gerando criaturas novas e seus pares. É fato que as mutações contribuem para a variabilidade genética e que ao afetarem seletivamente o "liga-e-desliga" das redes gênicas que atuam no desenvolvimento leva às mudanças estruturais. Mas, por outro lado, evolução é um fenômeno essencialmente populacional, envolvendo mudanças nas frequências gênicas ao longo de gerações no espaço geográfico. Aspectos vantajosos triados pela seleção 
natural tendem gradualmente a se espalhar enquanto os desfavoráveis tendem a diminuir ou serem eliminados. $O$ acúmulo de novidades evolutivas e as pressões seletivas diferenciais no espaço geográfico terão implicações na morfologia, fisiologia e comportamento dos organismos como ajustes locais. Por outro lado, mudanças abruptas na frequência gênica geradas por fatores estocásticos também são frequentes e conduzem a alterações substanciais no acervo gênico ("gene pool"). Os dois fatores interferem nos diferentes mecanismos de especiação4.

4) “Evolução é só uma teoria". - Outro mito moderno. Reflete a falta de compreensão do que vem a ser hipótese, teoria, fato e lei no contexto da investigação científica. Para o leigo, uma teoria é algo pouco além de um palpite, bem distante de uma suposta verdade religiosa revelada. Estudar evolução é desvendar a história da vida na Terra, investigar origem e as adaptações das espécies, incluindo a nossa. Significa recuperar padrões e esclarecer processos subjacentes à diversidade. É querer saber o que aconteceu para depois tentar saber como e o porquê. Sendo um metafenômeno, inclui aspectos que ocorrem em diversos níveis de generalidade e organização. Daí, se falar de evolução molecular, epigenética, flutuações na frequência gênica de populações, irradiação adaptativa, triagem de espécies, extinções em massa, biologia filogenética etc. 0 trabalho do biólogo evolucionista é comparável ao de um detetive criminalista interessado em reconstituir um fato criminal pelas pistas deixadas. Fá-lo através do confronto entre hipóteses quanto ao acontecido. Permanece a hipótese mais bem sustentada por evidências e com maior poder de explicação. Deve ser considerada provisória, passível de teste diante de novo conjunto de evidências e circunstâncias. O metafenômeno da evolução pode ser trabalhado em dois níveis, com enfoques e perspectivas diferentes: micro e macroevolução. No primeiro caso, o enfoque é sobre processos evolutivos atuantes em curta escala temporal, estudados por geneticistas e ecólogos de populações. Podem elaborar protocolos experimentais para testar suas hipóteses lidando com organismos que produzem grande número de descendentes através de gerações e verificar como variabilidade genética, mutações, dispersão, recombinação gênica, deriva genética e seleção natural estão relacionadas. No segundo caso, há muitas restrições. É a evolução estudada no

\footnotetext{
${ }^{4}$ Geração de novas espécies a partir de espécie ancestral por divergência, isolamento e diversificação com base em mudanças hereditárias obtidas e acumuladas.
} 
tempo geológico com espécies táxons supraespecíficos, realizada por sistematas e paleontólogos. Sendo assim, está condicionado às inferências extraídas de fósseis e constatações geológicas.

5) "Seleção natural ocorre ao acaso". - Muita gente acredita que a seleção natural é um processo aleatório. 0 mito está atrelado à crença religiosa de que há uma intervenção direta e direcional na natureza por parte de um Deus pessoal, no contexto de uma corrente teológica teísta ${ }^{5}$. Logo, o contraexemplo seria o acaso, associado a seleção natural. Além de carecer de base racional, há má compreensão do conceito de seleção natural. Evolução não é sinônimo de seleção natural, há outros mecanismos envolvidos ${ }^{6}$. Seleção natural explica as adaptações. Se, por um lado, mutações podem ocorrer devido ao acaso, a seleção natural é um processo natural direcional, nunca ao acaso. Indica que há sobrevivência diferencial entre indivíduos de uma população, de modo que, ao longo de gerações, variações vantajosas tendem a aumentar em frequência nas populações. Sendo assim, pode-se fazer uma projeção e com isso, estabelecer controle.

6) Elo perdido e fóssil vivo. - Os dois refletem o peso dado aos fósseis nas questões evolutivas, como a prova objetiva direta de que evolução ocorreu. De fato, fósseis nos dizem que houve sucessões de faunas e floras, formas intermediárias, condições climáticas bem diversas das atuais, distribuições geográficas particulares e extinções. Mas isso gerou mitos. No primeiro caso, - o elo perdido -, há o mito da existência de espécies ancestrais identificáveis por fósseis que podem ser indicadas como ponte entre linhagens evolutivas morfologicamente díspares. No segundo caso - fóssil vivo -, é um mito baseado numa má conceituação, referindo-se a formas arcaicas sobreviventes reconhecidas pela retenção de aspectos primitivos herdados de antigas linhagens. 0 mito do elo perdido foi derrubado com o advento do cladismo, na década de 1960. Até então, era comum a recuperação das relações de parentesco entre as espécies pela de busca por fósseis-chave, com base na primitividade estrutural e antiguidade. Todo fóssil era rotulado como ancestral em potencial. No cladismo, essa busca desenfreada foi abandonada em prol da descoberta de grupos-irmãos ${ }^{7}$.

\footnotetext{
${ }^{5}$ De forma contrária, Lamarck, Galileu, Newton, Descartes e outros cientistas tinham uma postura dita deísta. Admitiam a existência de um Deus pessoal que, no entanto, ao criar as leis naturais, não intervinha mais na sua criação. Para Ele, de nada lhe adiantaria rezar, pois como um bom juiz não poderia favorecer ninguém; nesse sentido, não faz sentido "benção" ou "castigo". Seus domínios estariam somente no campo transcendental. ${ }^{6}$ Entre eles, inércia filogenética (i.e., retenção de aspectos ancestrais e restrições físicas, baixa evolubilidade) e a correlação de caracteres (i.e., um traço fenotípico favorecido por seleção pode estar associado a outros que são neutros ou mesmo deletérios).

${ }^{7}$ táxons cuja relação em termo de ancestralidade comum é justificada pela presença de novidades evolutivas compartilhadas pelos descendentes de uma espécie ancestral mais recente, exclusiva deles.
} 
Ao invés de se apontar subjetiva e intuitivamente quem seria a espécie ancestral, passou-se a trabalhar metodologicamente com ancestrais hipotéticos. Por outro lado, o termo fóssil vivo é contraditório pois se dá ênfase aos atributos primitivos retidos por um sobrevivente de uma linhagem antiga e não às suas novidades evolutivas.

7) “Genes deterministas". - Dentro de uma corrente ufanista e reducionista gerada pelas grandes descobertas recentes da genética molecular, entre elas, o mapeamento genômico, mitos modernos foram gerados. Um deles está associado à "cura gênica", em que certos aspectos genéticos indesejados poderiam ser localizados, tratados e eliminados, como no preconceituoso caso do "gene da homossexualidade". Ao contrário do que o mito sugere, a seleção natural atua sobre complexas redes gênicas de modo que, a resposta às situações ambientais pode ser algo muito complexo, em "sintonia fina", gerando fenótipos diferentes, mas com o mesmo genótipo.

8) “Teoria da evolução é pessimista". - Teorias não são elaboradas para ter maior ou menor apego popular. Tal colocação não faz sentido. Elas tentam descrever algum aspecto da realidade objetiva, doa a quem doer. A "visão pessimista" deriva da ideia popular de que a natureza é um reality show de "banho de sangue", com o domínio dos mais fortes sobre os mais fracos. Programas televisivos sobre "natureza selvagem" exploram o aspecto eliminador da seleção natural, com exemplos de predação de todos os tipos, de modo a pensarmos sempre na evolução como um processo no qual a felicidade de uns é gerada à custa da infelicidade de outros. Mas a seleção natural também atua de forma construtiva e acumulativa, gerando amizades permanentes e intricadas cooperações.

9) Darwinismo social. - O mal uso do darwinismo resultou em distorções usadas como justificativas racionais para diversas políticas antissociais. Eugenia (i.e., depuração racial humana através de cruzamentos seletivos), aristogênese (i.e., elite socioeconômica selecionada favoravelmente), antropocentrismo (i.e., homem no ápice da evolução) são algumas dessas distorções. Mas a história tem raízes bem mais antigas. Desde tempos remotos, a escravidão era praticada contando sempre com o suporte religioso subjacente. Subjugar nações para impor-lhes à força 
culturas, normas e comportamentos, aniquilando suas culturas, era a regra. 0 escravizado era o inferior, o menos capaz. O eurocentrismo - a perspectiva de que os europeus caucasianos são intelectual e culturalmente superiores -, já se manifestava desde a Idade Média. Com a queda do sistema escravagista, as práticas inescrupulosas de exploração da mão-de-obra continuaram. Nesse contexto, o darwinismo social teve suas raízes entre grupos conservadores dos Estados Unidos, representado pelo sociólogo norte-americano William Sumner (1840-1910), na transição dos séculos XIX e XX, defensor da eliminação dos inaptos, deficientes e incompetentes e a manutenção a qualquer custo dos privilégios da elite economicamente privilegiada. Daí a ideia da utilização da "sobrevivência do mais apto", do filósofo Herbert Spencer, como slogan e justificativa científica para os excessos do liberal capitalismo. Então, racionalizou-se o apartheid social como uma tentativa de evitar a degenerescência causada por miscigenações e a preservar o banco genético de "raças superiores". No entanto, cabe dizer que as famílias de Darwin e dos Wedgwood ${ }^{8}$ se notabilizaram pelo ativismo político em prol de causas sociais avançadas, como direito de voto feminino, laicidade do Estado e o abolicionismo. $\mathrm{O}$ brasão símbolo dos Wedgwood exibia um negro ajoelhado com corrente quebrada e continha a inscrição: “Am I a man and a brother?" E é famosa a nota de repúdio à escravidão de Charles Darwin na sua passagem pelo Brasil.

10) "O homem veio do macaco." - Talvez seja o mito mais difundido. A origem do homem - "o mistério dos mistérios" começou a ser esclarecida por Darwin, em 1868, na Descendência do Homem. Para início de conversa, para um fundamentalista religioso não faz qualquer sentido a expressão "veio de..." já que, para ele, só faz sentido "criado por...", e isso remete à fábula bíblica da criação divina a partir do barro. A aversão ou pânico de certas pessoas em admitir o estreito parentesco com símios ou que somos upgrade de macacos é conhecida por pitecofobia. Dentro do pensamento evolucionista é fato que o homem compartilha ancestrais em comum com todos os seres vivos. A similaridade genética revela essa relação de parentesco (vide teste de paternidade através da comparação de sequências de DNA). Esse

\footnotetext{
${ }^{8}$ A família Wedgwood era muito próxima daquela de Darwin. Eram ferrenhos opositores ao comércio de escravos entre a África e os Estados Unidos. O avô de Darwin, Erasmus Darwin, era muito amigo de Josiah Wedgwood, famoso ceramista britânico. Charles Darwin se casou com Emma Wedgwood, sua prima.
} 
relacionamento é geneticamente mais estreito, como não poderia deixar de ser, com os demais primatas. Uma vez que somos primatas, tivemos inevitavelmente ancestrais com aspecto de macaco. Dos macacos antropomórficos (Hominoidea), o chimpanzé-comum (Pan troglodytes) e o bonobo (Pan paniscus) são os mais próximos (99\% de similaridade genética), a ponto de se dizer que somos o terceiro chimpanzé! No entanto, entre os chimpanzés e nossa espécie Homo sapiens há espécies de vários gêneros (i.e., Sahelanthropus, Orrorin, Ardipithecus, Australopithecus, Kenyanthropus, Paranthropus) conhecidas somente de fósseis. Somos sobreviventes dessa linhagem (Hominini) da mesma forma que os chimpanzés são da linhagem deles (Panini). Portanto, nenhum chimpanzé ou qualquer outro macaco sobrevivente de sua própria linhagem pode ser candidato a ser ancestral de Homo sapiens. Por outro lado, há várias espécies extintas de seres humanos do gênero Homo (e.g. H. heidelbergensis, H. habilis, H. erectus, H. floresiensis, H. neanderthalensis). Todas elas derivam de uma ancestral comum que, para certos paleoantropólogos, seria Australopithecus sediba, do Pleistoceno da África meridional. Das espécies de Homo, H. neanderthalensis é grupo-irmão de H. sapiens. Logo, a espécie que nos deu origem só poderia ter sido do mesmo gênero, um outro ser humano extinto. Alguns paleoantropólogos arriscam dizer que seria Homo heidelbergensis que viveu entre 600-350 mil anos na Europa.

A teoria de evolução permanece como sendo a melhor explicação para a história da vida no nosso planeta. Ela tem sido corrigida e reforçada com novas evidências empíricas provenientes de áreas diversas das ciências biológicas e geológicas canalizadas numa explicação comum. Não há qualquer evidência contrária de base racional (bastaria achar um osso de mamífero no Cambriano para derrubar a teoria). Paleontólogos, geneticistas, embriologistas, ecólogos, etólogos, geólogos, anatomistas, sistematas e biogeógrafos têm contribuído continuamente para a montagem desse fascinante quebra-cabeça.

\section{(cc) Br}

Este trabalho está licenciado com uma Licença Creative Commons - Atribuição 4.0 Internacional. 